\title{
Growth and persistence of diverse intertidal crusts: survival of the slow in a fast-paced world
}

\author{
Megan N. Dethier ${ }^{1, *}$, Robert S. Steneck ${ }^{2}$ \\ ${ }^{1}$ Department of Zoology and Friday Harbor Laboratories, University of Washington, 620 University Road, Friday Harbor, \\ Washington 98250, USA \\ ${ }^{2}$ Darling Marine Center, University of Maine, Walpole, Maine 04573, USA
}

\begin{abstract}
Encrusting algae are conspicuous components of hard-substratum benthic communities in the photic zone despite being poor competitors and slow growers. Little is known about their growth rates or about mechanisms controlling key processes such as wound healing and surviving overgrowth. We manipulated 12 crustose species (including red and brown algae and a lichen) from the intertidal zone of Washington, USA, studying their varying responses to identical experimental conditions. Three of 8 crust species tested showed increased growth rates with size. Species healed from standardized wounds at different rates and using different mechanisms (e.g. lateral vs vertical regeneration) as seen in cross-sections. Three species showed altered growth rates at unwounded margins of wounded crusts, suggesting intrathallus communication. Year-long experiments involving simulated overgrowth showed that some species can maintain healthy tissue in a covered area, and one (the coralline Lithothamnion phymatodeum) even grew new tissue there. Other species gradually lost color, thickness, and area in covered areas. Hildenbrandia occidentalis survived remarkably well when covered, possibly due to its very slow growth and low metabolic demand. One suggested mechanism underlying the high variation in responses among crusts is the degree to which their thalli may be anatomically integrated by features such as cell fusions; physiological work testing translocation via these features is needed. Other mechanisms allowing persistence include rapid wound healing and frequent recruitment.
\end{abstract}

KEY WORDS: Algal crusts · Regeneration · Herbivory · Overgrowth · Integration · Cell fusion · Hypothallus · Anatomy · Competition

\section{INTRODUCTION}

Encrusting algae are conspicuous components of rocky intertidal and shallow subtidal communities worldwide. The encrusting morphology of algae evolved early (Precambrian: Grant et al. 1991) and often; this form is found in all major phyletic divisions of benthic macroalgae as well as marine lichens. Crusts are slowgrowing (Dethier 1994) and virtually 2-dimensional and thus easy to overgrow, yet they cover much primary space (e.g. Bosence 1983). While algal crusts are present on most hard substrata in the photic zone, they are the dominant algal functional group in areas of high disturbance potential (sensu Steneck \& Dethier 1994), such as

*E-mail: mdethier@u.washington.edu from herbivores or sand scour, and areas of high stress (low productivity potential), such as high in the intertidal zone or low in the photic zone (Vadas \& Steneck 1988, Dethier 1994, Steneck \& Dethier 1994; also reviewed in Kaehler \& Williams 1998). Crusts also manage to persist as an understory in many habitats dominated by erect macroalgae, although they are susceptible to overgrowth by other hard substratum-dwelling species (reviewed in Dethier 1994, Airoldi 2000). Given this apparent ecological and evolutionary success, surprisingly little is known about their functional characteristics. This paper examines differences among crusts in their ability to respond to ecological stressors such as wounding and overgrowth. We explore the mechanisms they use to maintain their abundance in the face of extrinsic factors that must make survival difficult for a group of organisms that grow at a rate of only a few $\mathrm{mm} \mathrm{yr}^{-1}$. 
After settlement, ecological success for any sessile marine organism depends on its ability to grow and persist. Algal crusts are different from erect algae in their growth patterns and requirements. They live in the benthic boundary layer with only the surface of their thallus directly exposed to light and nutrients. Most of their mass (not just a holdfast) requires primary or secondary substratum to grow, and their active regions of areal growth are the margins. Thus encrusting algal growth is largely manifest as enlarging prostrate disks. For crusts, as with many clonal invertebrates (e.g. Hughes 1984), critical ecological parameters such as reproductive output and probability of survival may be size-rather than age-based. Factors affecting radial growth are thus likely to be important for their ecological success. In addition, the ecological performance of any sessile organism, perhaps especially crusts, which are poor competitors, may be enhanced if they can respond to external stimuli by allocating resources to starved portions, or by initiating a growth response to 'escape' a perceived threat. Such responses are only possible if the organism is physiologically integrated, i.e. if its different portions share resources, growth substances, or functions (Jackson et al. 1985), as has been shown in sessile encrusting invertebrates (e.g. Ayling 1983 for sponges; Lidgard \& Jackson 1989, Jackson \& McKinney 1990, Miles et al. 1995 for bryozoans; Sammarco \& Coll 1990 for corals).

Physiological integration within plants requires translocation. This is known to occur in some large algae such as kelps (Nicholson \& Briggs 1972) and Caulerpa (Williams 1984), and in nonphotosynthetic parasitic crustose algae such as Harveyella (Goff \& Cole 1973, Kremer 1983, South \& Whittick 1987) and the coralline Kvaleya epilaeve (e.g. Adey \& Sperapani 1971). Anatomical characters such as trumpet hyphae, siphonaceous growth, cell fusions, or pit connections have been identified as necessary for translocation. Primary pit connections (or 'pit plugs') may allow vertical translocation (within filaments), whereas secondary pits and cell fusions may allow lateral translocation (among filaments), although proof of these functions has been 'elusive' (Pueschel 1990, Murray \& Dixon 1992). Some evidence for such translocation comes from nonphotosynthetic coralline algae, which appear to gain all their nutrition through relatively few rhizoids into host cells (Kvaleya has cell fusions, and Ezo may use secondary pits) (Adey et al. 1974, Steneck 1986). An alternative avenue for translocation may occur in algae with a hypothallus (or medulla), a multilayered, laterally directed basal region composed of large cells, with their primary pits forming conduits parallel to the substratum. Denizot (1968) hypothesized that the hypothallus is a necessary element for lateral transport of nutritive substances. Hypothallial cells might transport photosynthates via primary pits in red crusts, or by plasmodesmata or intercellular sieve elements in browns, providing an additional mechanism for physiological integration among species lacking cell fusions.

Many species of encrusting algae, primarily in the Rhodophyta and Phaeophyta, possess such a basal hypothallus, which ranges from indiscernable to very thick (e.g. Bosence 1983). The upper portion of the thallus of most crusts, in contrast, consists of vertically directed filaments called the perithallus, or cortex. In many crustose corallines, there are cell fusions and secondary pits between these filaments. Crust growth thus occurs in 2 directions: laterally, making the disk area larger, and vertically, making the crust thicker. When possible, both of these growth directions were quantified in the experiments. The lichen Verrucaria mucosa differs substantially from the other crusts studied in that it lacks these obvious layers, consisting instead of indistinct filaments of green algal cells interwoven by fungal hyphae, which are known to anastomose in some species (Jahns 1973).

In this paper, we describe patterns of crust performance (i.e. survival and growth) under a variety of experimental conditions designed to simulate the ecological pressures of wounding (as from an herbivore or scouring action) and overgrowth. Experiments involved 12 species including both calcified (coralline) and non-calcified crusts (fleshy reds, browns, and a lichen). Differences in the performance of crusts are then related to their anatomical and ecological characteristics.

\section{MATERIALS AND METHODS}

The crust species used in the experiments are shown in Table 1, along with some key anatomical characters that might influence growth or integration. Not all species were used in each experiment because of limited time and crust availability. Normal habitats and distributions for all species are described in Steneck \& Paine (1986) and Dethier (1987); all are primarily intertidal species, except for Peyssonnelia pacifica, which is more common in the shallow subtidal zone. All samples for experimental manipulations were collected on San Juan Island $\left(48^{\circ} 30^{\prime} \mathrm{N}, 123^{\circ} \mathrm{W}\right)$, Washington, USA. Chips of rock with attached crust were chiseled from the bedrock and transplanted into Petri dishes filled with Koppers Splash Zone Compound putty. Once the putty hardened, crusts readily extended over it and their marginal growth was measured in 2 ways (Fig. 1): as maximum lateral growth from the margin and as area grown (measured in $\mathrm{mm}^{2}$ with an overlay grid of small squares). Thallus thickness was also measured in 
Table 1. Summary of the crust species used in the experiments, including key anatomical characteristics. Information sources are listed below. 'Petrocelis' is the original designation of the crustose tetrasporophyte of Mastocarpus papillatus, used here for brevity. Hypo = hypothallus (medulla); peri = perithallus (cortex).

\begin{tabular}{|c|c|c|c|c|}
\hline Species & Abbreviation & Cell fusions & Hypothallus & Secondary pits \\
\hline $\begin{array}{l}\text { CORALLINE RHODOI } \\
\text { Lithothamnion } \\
\text { phymatodeum }^{\text {a }}\end{array}$ & L.PHY & Many & Thick & No \\
\hline $\begin{array}{l}\text { Pseudolithophyllum } \\
\text { whidbeyense }^{\mathrm{a}}\end{array}$ & P.WHID & Many & Thick & No \\
\hline $\begin{array}{l}\text { Pseudolithophyllum } \\
\text { neofarlowii }^{\text {a }}\end{array}$ & P.NEO & Many & Thin (1-2 layers) & No \\
\hline $\begin{array}{l}\text { Lithophyllum } \\
\text { impressum }^{\mathrm{a}}\end{array}$ & L.IMP & 0 & Thin (1 layer) & Many, large \\
\hline $\begin{array}{l}\text { FLESHY RHODOPHY } \\
\text { ‘Petrocelis' }{ }^{\text {b }}\end{array}$ & PETR & $\begin{array}{l}\text { Small, both } \\
\text { hypo. + perithallus }\end{array}$ & $\begin{array}{l}\text { Medium, between peri. } \\
\text { and subhypothallus }\end{array}$ & Yes \\
\hline $\begin{array}{l}\text { Peyssonnelia } \\
\text { pacifica }^{\mathrm{c}}\end{array}$ & P.PAC & $\begin{array}{l}\text { Few (between } \\
\text { hypothallial cells) }\end{array}$ & 1 layer, large cells & Yes \\
\hline $\begin{array}{l}\text { Rhodophysema } \\
\text { elegans }^{\mathrm{d}}\end{array}$ & R.ELE & $\begin{array}{l}\text { Few, both } \\
\text { hypo. + perithallus }\end{array}$ & Thin & Yes \\
\hline $\begin{array}{l}\text { Hildenbrandia } \\
\text { occidentalis }^{\mathrm{f}}\end{array}$ & H.OCC & 0 & Indiscernible & Many, small \\
\hline Hildenbrandia rubra ${ }^{\mathrm{f}}$ & H.RUB & 0 & Indiscernible & Many, small \\
\hline \multicolumn{5}{|l|}{ PHAEOPHYTA } \\
\hline Ralfsia pacifica $^{\mathrm{C}}$ & R.PAC & 0 & Thick & No \\
\hline Ralfsia confusa ${ }^{g}$ & R.CON & 0 & 1-2 layers & No \\
\hline \multicolumn{5}{|l|}{ LICHEN } \\
\hline Verrucaria mucosa ${ }^{\mathrm{e}}$ & V.MUC & 0 & None & No \\
\hline \multicolumn{2}{|c|}{$\begin{array}{l}\text { Information sources for anatomical features: } \\
\text { a Steneck \& Paine (1986), Steneck unpubl. data } \\
\text { b Denizot (1968), Dixon \& Irvine (1977), pers. obs. } \\
\text { c pers. obs. }\end{array}$} & \multicolumn{3}{|c|}{ 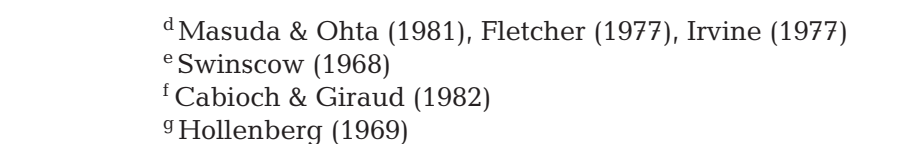 } \\
\hline
\end{tabular}

several experiments. Reproductive state was not systematically quantified; corallines have obvious surface conceptacles but the fertility of fleshy crusts cannot be assessed without destructive sampling, which we needed to avoid in the experimental procedures. In addition, the species used are fertile at different times of year (Dethier 1987) such that the end of an experiment would not correspond to the fertile period for all species.

Experiments were performed at the Friday Harbor Laboratories using a 'common garden' approach. Because most of the corallines and some of the fleshy crusts live
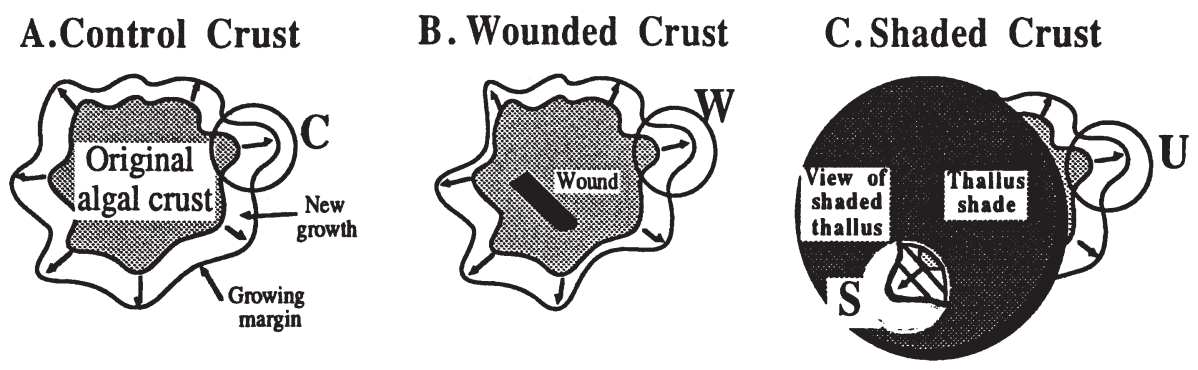

Fig. 1. Diagrammatic illustration of manipulations and growth measurements of encrusting algal transplants. (A) Control crust. The original transplanted thallus is the center (shaded) region; new growth is white. Measurements of radial growth of controls $(\mathrm{C})$ were in the direction of the outward pointing arrows. (B) Wounded crust. Growth rates were measured at the point of maximum lateral growth (W). (C) Shaded crust, with a PVC disk covering much of its area. Growth and thallus thicknesses were measured on shaded (S) and uncovered (U) portions of the margin of shaded crusts 
of PVC slats and hung it $20 \mathrm{~cm}$ beneath the water surface from the floating breakwater; it had no herbivores, and the crusts experienced full sunlight and plenty of water motion around the slats (described in Dethier 1994). Crusts and raft were lightly cleaned every 2 wk to remove epiphytes. Control samples (transplanted but not otherwise manipulated, e.g. wounded or shaded) of all species thrived and grew under these conditions, which were similar to those in large, low intertidal pools.

To examine whether any crust species show growth rates that increase with thallus size (size-dependent growth), we transplanted chips of rock with crusts of different sizes (60 to $800 \mathrm{~mm}^{2}$ ) into Petri dishes of putty and allowed them to grow on the raft for 2 to $3 \mathrm{yr}$. In addition, lateral growth rates of undisturbed crusts in the field were measured over small disks of putty placed adjacent to growing edges. Initial size versus area added per time were compared with least squares linear regressions of log transformed data.

The speed and anatomical changes with which crusts respond to injury were examined in 2 experiments. Firstly we quantified the ability to recover from intense disturbance, i.e. extensive biomass loss (thickness and/or areal coverage) following a destructive event. The disturbance was either artificial brushing that mimicked herbivory or actual herbivore feeding (experiments described in Dethier 1994). When these experiments were terminated, dishes were placed on the raft, where crusts were allowed to recover for 6 to $9 \mathrm{mo}$, and their changes in percent cover were quantified. Secondly we made wounds in crusts in a uniform fashion using a hand-held V-shaped linoleum cutting tool. Deep wounds (on $\mathrm{N}=5$ samples per species) were made by cutting a 'trench' in the crust that was approximately $325 \mu \mathrm{m}$ wide, 1 to $2 \mathrm{~mm}$ long, and deep enough to reveal the substratum. Shallow wounds $(\mathrm{N}=5)$ of similar length and width were made more surficially and did not reach the substratum (depth varied with crust thickness). Control crusts $(\mathrm{N}=5)$ were put in the same dishes and hung on the common-garden raft with them, but were undisturbed. Crusts were re-injured 3 times (at 0, 4, and $10 \mathrm{mo}$ ). After $1 \mathrm{yr}$, we measured lateral crust growth (mm) and area (Fig. 1B). Because sample sizes in these and other experiments were small and sometime unequal (e.g. if a sample died), for each species the growth rates in the 3 treatments (deep, shallow, and no wounds) were compared using a nonparametric ANOVA (Kruskal-Wallis) and posthoc multiple comparisons (only possible when sample sizes were equal). For the thicker fleshy crusts, healing mechanisms were examined by making hand crosssections of the crust at right angles through the injured and healed regions.

We subjected different species to simulated partial overgrowth by blocking all light to a large part of each experimental thallus. Crust samples (1 per species in each of 5 replicate dishes) were puttied in a symmetrical fashion in a Petri dish such that a central disk of opaque grey PVC could be bolted onto the middle, covering most (average \pm SD of $78 \pm 8 \%$ ) of each thallus. A thin stainless steel washer was put below the disk to allow some water motion over the covered surfaces of the crusts; sediment did not accumulate under the disk. However, because of the limited water flow under the disk, it is likely that these samples suffered not only light but nutrient stresses, as would a crust overgrown by another sessile organism in nature. Disks were removed and crusts cleaned every 6 mo. Survival (change in percent cover), growth (area and lateral growth) and thickness of the crusts were monitored through $1 \mathrm{yr}$ for both the covered and uncovered portions of each sample (Fig. 1C). Control samples ( $\mathrm{N}=$ 5 of each species) were placed in dishes on the same raft and similarly measured. We tested 4 species one year and 4 others the next; for the second set, we also

Table 2. Maximum growth rates for all 12 species and results of the size-dependent growth experiments for the 8 crust species used. Max. growth: maximum lateral growth $\left(\mathrm{mm} \mathrm{yr}^{-1}\right)$ ever observed for that species (in field or lab). r: correlation coefficient (logarithmic) of area at the beginning of the experiment vs new area added. nd = no data

\begin{tabular}{|lcccc|}
\hline & Max. growth & $\mathrm{r}$ & No. of samples & Significance \\
\hline Lithothamnion phymatodeum & 12 & 0.81 & 10 & $\mathrm{p}<0.005$ \\
Pseudolithophyllum whidbeyense & 16 & 0.12 & 24 & $\mathrm{p}>0.50$ \\
Pseudolithophyllum neofarlowii & 4.3 & 0.54 & 0.22 & $\mathrm{p}<0.05$ \\
Lithophyllum impressum & 5.0 & 0.04 & 32 & $\mathrm{p}>0.20$ \\
'Petrocelis' & 13 & 0.13 & 18 & $\mathrm{p}>0.50$ \\
Peyssonnelia pacifica & 16 & $\mathrm{nd}$ & $\mathrm{p}>0.50$ \\
Rhodophysema elegans & 4.0 & $\mathrm{nd}$ & $\mathrm{n}$ & $\mathrm{p}>0.20$ \\
Hildenbrandia occidentalis & 2.0 & 0.58 & 23 & $\mathrm{p}<0.05$ \\
Hildenbrandia rubra & 1.2 & $\mathrm{nd}$ & \\
Ralfsia pacifica & 12 & $\mathrm{nd}$ & & \\
Ralfsia confusa & 2.0 & 2.0 & & \\
Verrucaria mucosa & & & \\
\hline
\end{tabular}


measured the thickness of any crust newly grown over the putty, both under and away from the disk. Two of the samples thought to be Ralfsia pacifica in the first year's transplants turned out to be $R$. confusa, so $R$. pacifica was transplanted again the second year. Growth and thickness were compared among treatments (controls and the covered and uncovered portions of experimental samples) using Kruskal-Wallis tests, as above.

\section{RESULTS}

\section{Size-dependent growth rates}

In all the experiments, growth rates (measured as lateral expansion of crusts) varied widely and consistently among species. Maximum rates observed (under any conditions) are listed in Table 2 . Rates differ by an order of magnitude, with the minimum shown by the thin red crust Hildenbrandia rubra, which never grew faster than $1.2 \mathrm{~mm} \mathrm{yr}^{-1}$ (and usually less than half that, see below). The fastest growing crusts included 2 fleshy reds, 2 calcified reds, and a brown (Table 2). Ralfsia fungiformis, which was not used in any of the

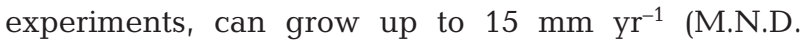
unpubl. data), putting it among the fastest. There were no general patterns of growth rate with algal division or presence of calcification.

We looked for a relationship between thallus size and growth in 4 coralline and 4 fleshy species. Only 2 coralline and 1 fleshy species (Fig. 2, Table 2) showed significantly faster growth with greater thallus size; this relationship was strong for the coralline Lithothamnion phymatodeum and weaker for the coralline Pseudolithophyllum neofarlowii and the fleshy brown Ralfsia pacifica. Thallus thickness was not measured in this experiment.

\section{Wound healing}

Recovery from intense disturbance (real or simulated herbivory) varied greatly among species. Precise rates cannot be quantified because of the variation in the amount and type of initial damage, but the species can be classified into 3 categories. Good regenerators regrew much of their original percent cover during the recovery period ( 6 to $9 \mathrm{mo}$ ) and included Rhodophysema elegans, Pseudolithophyllum whidbeyense, and 'Petrocelis'. Fair regenerators, which regained some cover, included Hildenbrandia rubra, Lithophyllum impressum, and the lichen Verrucaria mucosa. Ralfsia pacifica was sometimes a fair regenerator and sometimes poor, regaining little or actually losing more cover.
Healing rates in the wounding experiment are illustrated in Fig. 3. At 2 mo following standardized wounding, many specimens showed complete healing of their shallow wounds but much less of the substratum-baring deep wounds. At 4 mo (Fig. 3B) degree of healing of deep wounds was scored on a scale of 1 to 5 . There was

\section{LITHOTHAMNION PHYMATODEUM}

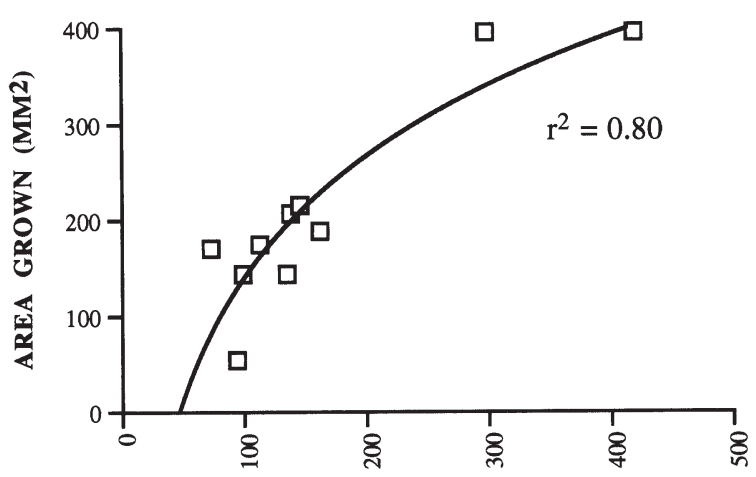

PSEUDOLITHOPHYLLUM NEOFARLOWII

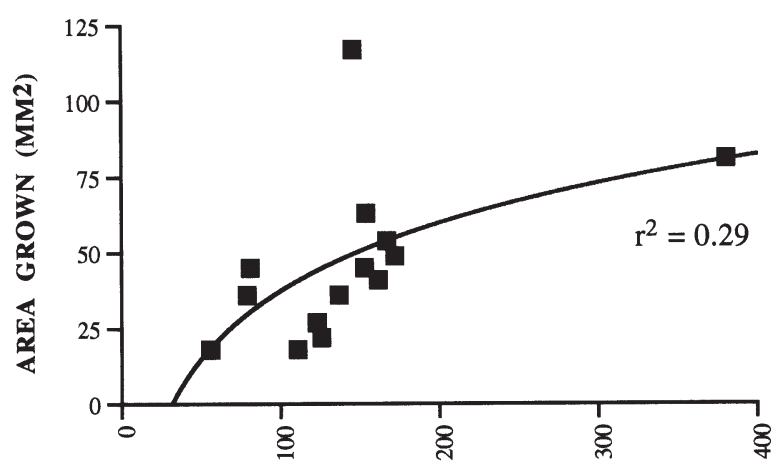

RALFSIA PACIFICA

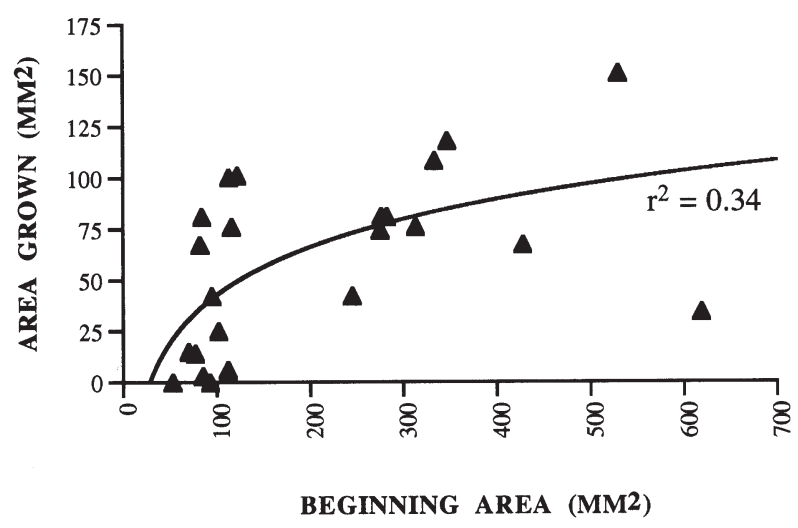

Fig. 2. Species showing size-dependent growth. The $x$-axis shows initial crust size in $\mathrm{mm}^{2}$, and the $y$-axis plots the area added $\left(\mathrm{mm}^{2}\right)$ after $1 \mathrm{yr}$ (for the 2 corallines) or $3 \mathrm{yr}$ (for Ralfsia pacifica). $\mathrm{p}$-values of regression lines are listed in Table 2 


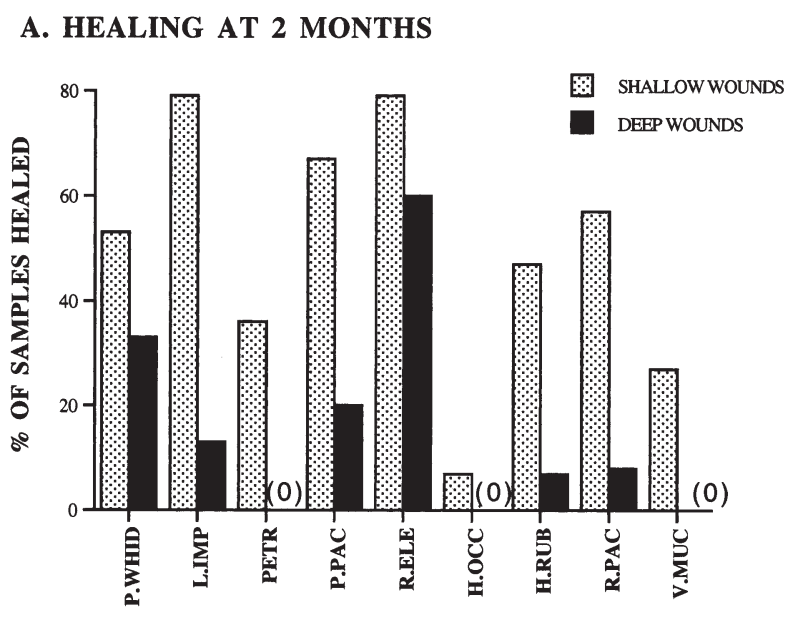

B. HEALING FROM DEEP WOUNDS, 4 MONTHS

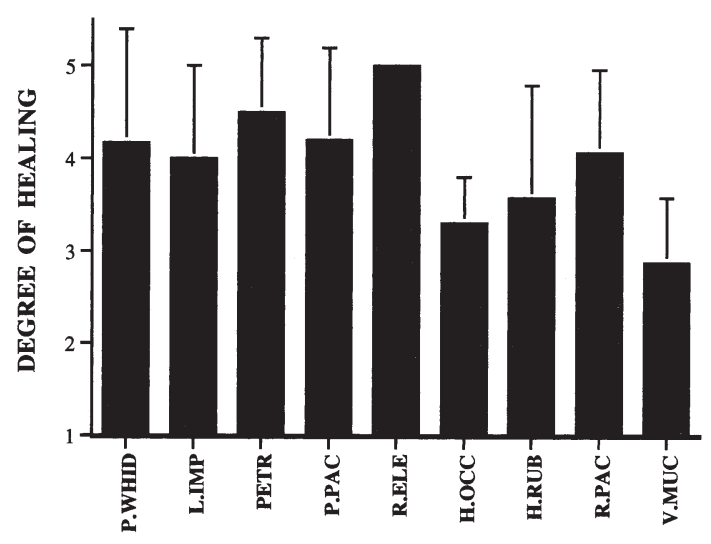

Fig. 3. Rates of healing of all crusts in the wounding experiment. Abbreviations and ordering as in Table 1. (A) Comparison of the proportion of experimental wounds healed after 2 mo in the deep-wounding vs shallow-wounding experiments. $0=$ no samples had completely healed. (B) Degree of healing of deep wounds after $4 \mathrm{mo}$, based on a subjective scoring system: $1=$ no healing; $2=$ part of the rock still showing but with some new growth in the trench; $3=$ deep trench, but bottom and sides all lined with new growth; $4=$ trench mostly filled; $5=$ no trace of wound. Each bar is a mean and 1 SD from 8 to 18 samples, depending on how many wounds had passed the $4 \mathrm{mo}$ interval by the final scoring period

general agreement between the healing ability quantified in this experiment and the qualitative observations in the intense-disturbance experiment described above. The red crust Rhodophysema elegans was the fastest healer, showing no trace of wounds after $4 \mathrm{mo}$; this may be due in part to its being very thin. The thick red 'Petrocelis' also was very fast, with an apparent acceleration of healing between 2 and 4 mo.

Healing mechanisms of shallow wounds for the 2 coralline species used have been described by Steneck et al. (1991). Lithophyllum impressum heals via vertical regeneration of damaged perithallial filaments, while Pseudolithophyllum whidbeyense readily reforms its
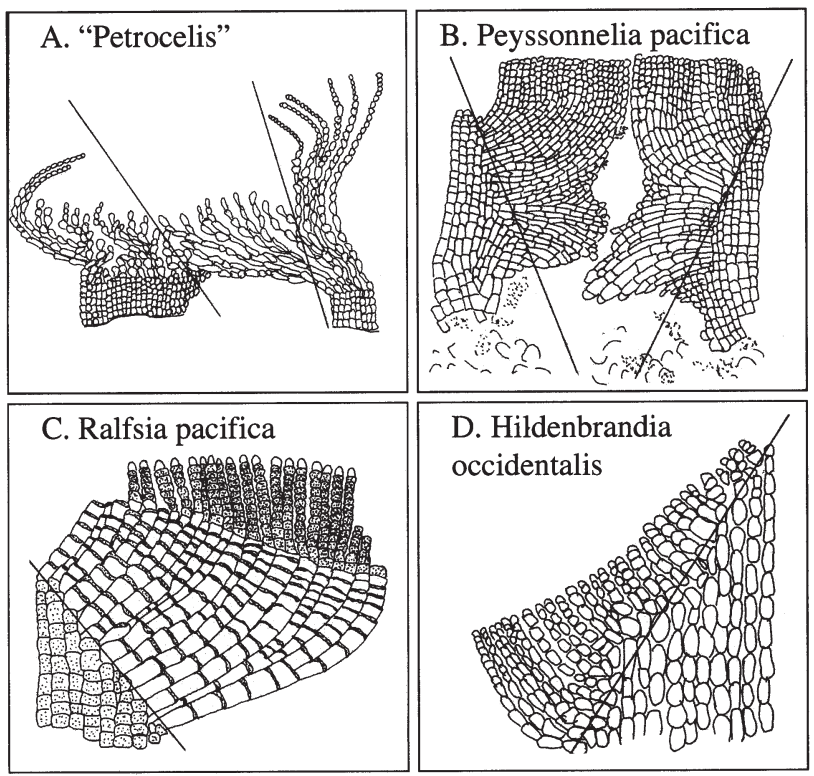

Fig. 4. Anatomical responses to deep wounds in 4 noncoralline crusts. The solid line indicates the plane of the wound $(A, B)$ both sides of the healing wound, $(C, D)$ just one side. Substratum in each case is at the bottom. (A) 'Petrocelis' heals rapidly due to infilling via lateral growth of fallen filaments. (B) Peyssonnelia pacifica and (C) Ralfsia pacifica have moderate wound healing rates, with lateral ingrowth of inflated perithallial cells. $R$. pacifica has plurilocular sporangia on the surface in this section. (D) Hildenbrandia occidentalis heals slowly via redirected growth of small perithallial cells

hypothallus for lateral regeneration, leading to rapid healing. Light microscopy of cross-sections of noncoralline species suggested that crusts heal deep wounds via several variations of these regeneration mechanisms. Rhodophysema elegans formed a very thin new growing edge (tissue source unknown) into the wound and then rapidly grew vertically. For 'Petrocelis', the perithallial filaments along the sides of the wound 'caved in' (Fig. 4A), while the hypothallus regrew into the wound and then produced new upright perithallial filaments. For Peyssonnelia pacifica and Ralfsia pacifica, each cut perithallial filament redirected growth inward to the wound (Fig. 4B,C); cut filaments close to the wound grew downward and laterally, acting as new hypothalli, while others eventually produced new vertically oriented perithallial filaments. Older specimens of $R$. pacifica, whose hypothallus was already senescent (Dethier 1987, 1994), did not heal effectively. In both these species, cells formed during wound healing were larger than those of the undisturbed perithallus. The 2 species of Hildenbrandia healed in very similar fashions, with each cut perithallial filament redirecting growth toward, or branching into, the wound (Fig. 4D). In the lichen Verrucaria mucosa, most samples were too thin to effectively visualize the healing process. In a few samples, the trench was clearly 


\section{GROWTH OF WOUNDED CRUSTS}

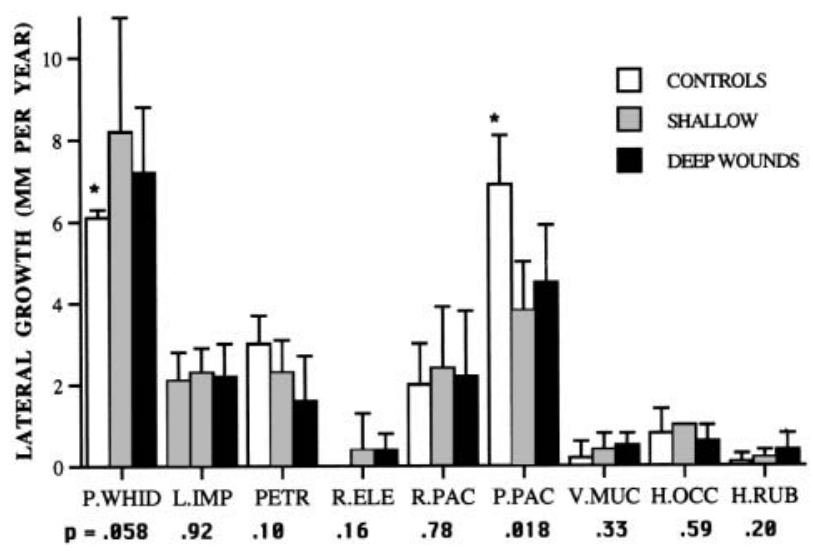

Fig. 5. Growth of wounded and control crusts, as measured by the maximum extent of lateral growth. Bars are means $(\mathrm{N}=5$ per treatment per species) with $1 \mathrm{SD}$. p-values for each parameter are the results of Kruskal-Wallis tests comparing the 3 treatments for each species. ${ }^{*}$ Treatment was different from the others according to post-hoc tests

filled from the sides by white tissue, made of fungal hyphae only; green algal cells eventually followed.

To determine if the performance of each crust thallus was affected by wounding, we measured lateral growth at the uninjured growing margin (Fig. 1B). Crusts varied widely in their growth rates, and in several species growth was significantly affected by wounding treatment (Fig. 5). In Peyssonnelia pacifica, lateral growth was significantly slowed in both wounding treatments relative to controls. 'Petrocelis' also showed somewhat reduced growth $(\mathrm{p}=0.10)$ when wounded. In contrast, Pseudolithophyllum whidbeyense showed acceleration of its lateral growth when wounded. We also measured the proportion of the perimeter of the crust sample that was growing out over the putty; some crusts had only a small projection of new growth at one spot (e.g. Hildenbrandia rubra, with $<1 \%$ of its perimeter growing after $1 \mathrm{yr}$ ), while others showed new growth around much of their perimeter (e.g. P. whidbeyense, with $78 \pm 32 \%$ [mean $\pm \mathrm{SD}$ ] growing). There is a strong correlation between the rate of lateral growth and the proportion of the perimeter that was growing $\left(r^{2}=0.91\right.$ for the wounding controls).

\section{Response to being covered}

When a large portion of a crust's thallus was covered with an opaque disk, most species suffered reduced survival of the covered portions (Fig. 6A), reduced rate of lateral growth over the putty (Fig. 6B), and reduced crust thickness (Fig. 7).
Analyses of the changes in crust area (Fig. 6A: expressed as a proportion of the original area to standardize for species showing size-dependent growth) show that for most species the covered portion of the crust shrank relative both to the uncovered portion of the same thallus and to the controls grown on the same raft. The main exception was the coralline Lithothamnion phymatodeum, which not only remained healthy under the disk but grew new pigmented (pink) tissue there (Fig. 6A). It showed no significant treatment effect (i.e. comparing controls, covered portions, and uncovered portions) in either survival or lateral growth (Fig. 6B). Although high variability in lateral growth among the 5 samples precluded a significant result in

\section{A. SHADING EFFECTS ON AREA}

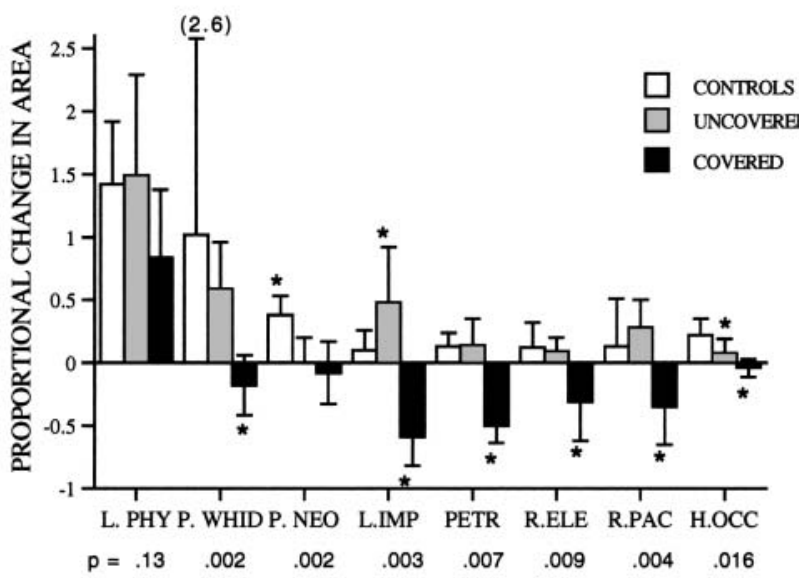

B. SHADING EFFECTS ON GROWTH

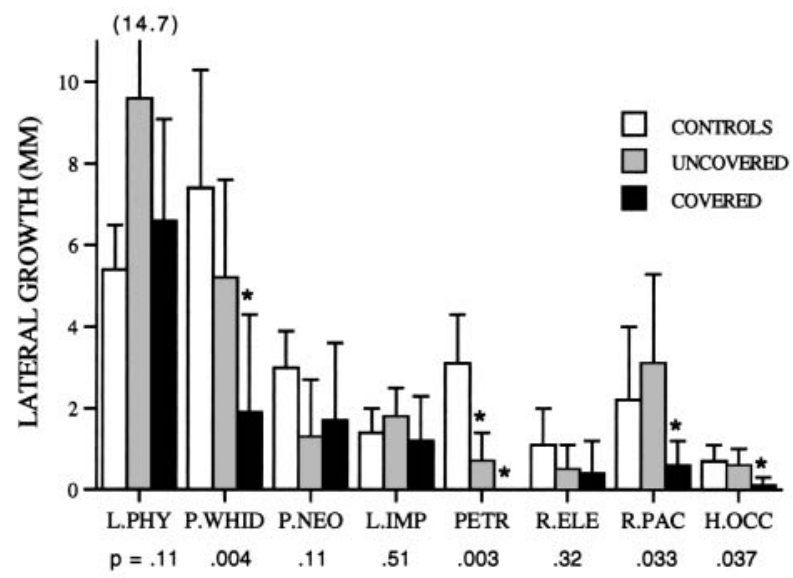

Fig. 6. Survival and growth of crusts in the artificial shading experiment. Means and $1 \mathrm{SD}$ are presented, both for the control samples and for the uncovered and the shaded portions of the shaded samples, for (A) proportional change in area [(area at end - initial area)/initial area] and (B) maximum lateral growth. For each parameter, p-values are for Kruskal-Wallis tests comparing the 3 treatments; ${ }^{*}$ treatment(s) different from the others 
A. SHADE EFFECTS ON CRUST THICKNESS

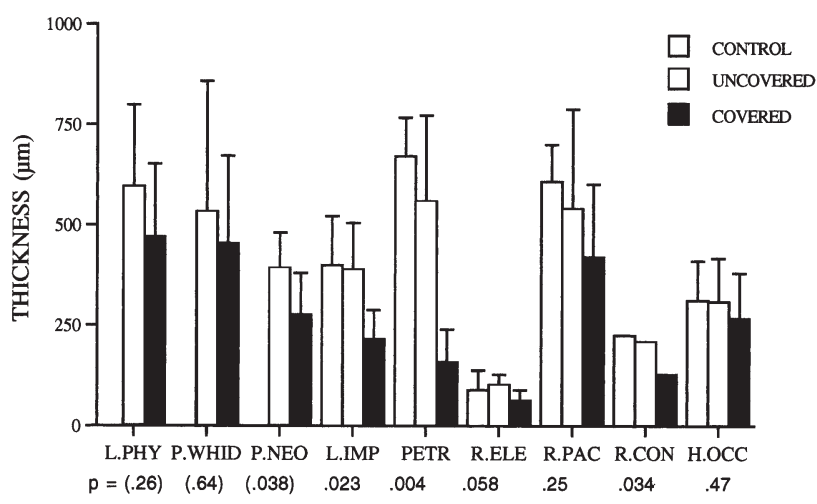

B. THICKNESS OF NEW GROWTH

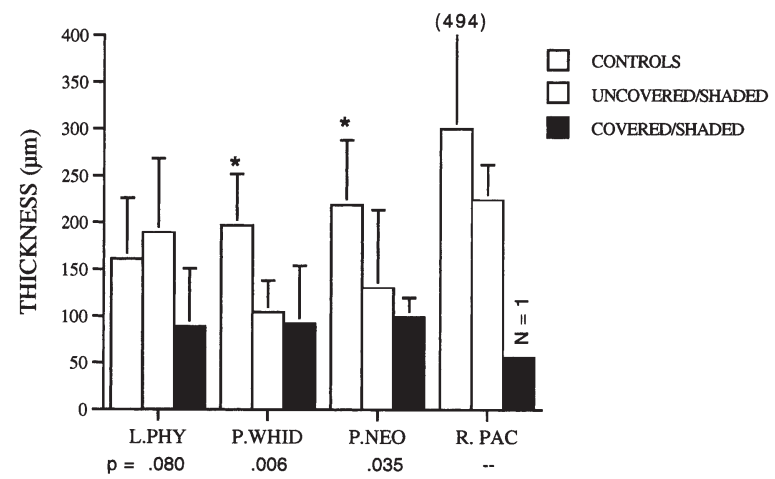

Fig. 7. Effects of artificial shading on thickness of crust samples. (A) Thickness of crust on the rock, both in shaded and uncovered portions of the original sample (mean and $1 \mathrm{SD}$ ). Ralfsia confusa (R.CON) had N $=2$ for each treatment, so no error bars are shown. p-values are from Kruskal-Wallis tests comparing all 3 treatments, except the values in parentheses, which are from paired $t$-tests on thickness values for those species. Multiple comparisons were not possible because of unequal values of N. (B) Thickness of new growth out over the putty for the 4 species where such sampling was attempted. p-values are from Kruskal-Wallis tests comparing thickness among the 3 treatments (not run for $R$. pacifica because of low sample sizes: only 1 sample showed covered growth)

the 3-treatment test, the trend was for the uncovered margin of the shaded samples to show accelerated growth relative to the control samples $(p=0.041$, Kruskal Wallis test among these 2 treatments). No other crust showed such a positive response.

While a second species of coralline, Pseudolithophyllum whidbeyense, showed straightforward declines in area and growth of only the covered areas (relative to the other 2 treatments), its congener $P$. neofarlowii showed a different pattern; the uncovered as well as the covered treatments declined in area and growth relative to the controls (Fig. 6A,B). The fourth coralline, Lithophyllum impressum, showed still a different pattern, with its uncovered portions showing improved survival and slightly accelerated growth relative to the controls. Both Pseudolithophyllum species remained alive and pink under the shade, while L. impressum turned pale or white.

Most of the fleshy species showed straightforward loss of both area and (to a lesser extent) growth rate of the covered portions relative to the 2 other treatments. Even 'Petrocelis' and Ralfsia pacifica, which normally grow fairly rapidly, paled and lost area over the course of the year. In 'Petrocelis', cross-sections of tissue beneath the cover showed that the perithallial filaments were being sloughed until only subhypothallus was present. However, Hildenbrandia occidentalis, a very slow-growing crust, persisted remarkably well when covered, paling slightly but showing only a small reduction in area and growth in this treatment.

Crust thickness also declined in the covered portions of all 9 species tested (signficantly in 5 species: Fig. 7A) relative to both other treatments (control thicknesses were not measured for the 3 corallines). In each case, old tissue was actively lost in the covered area. In addition, the thickness of new growth in covered areas (Fig. 7B) was reduced in each of the 4 species for which this parameter could be measured. For 2 species (Pseudolithophyllum whidbeyense and $P$. neofarlowii) the new growth was thinner even in the uncovered portions of the shaded thalli relative to the control samples (unequal values of $\mathrm{N}$ preclude multiple comparisons among these treatments), whereas L. phymatodeum did not show any reduction in thickness of its uncovered thallus portions.

\section{DISCUSSION}

The phylogenetically and anatomically diverse crusts used in these experiments illustrate some of the many ways that species in this flat and slow-growing functional group manage to persist in nature. In comparison with most macroalgae which grow at rates of many $\mathrm{cm}$ or even meters per year, most crusts have lateral growth rates of $<1 \mathrm{~cm} \mathrm{yr}^{-1}$. In addition, in a world where acquisition of light (and sometimes nutrients) requires growth over or above other organisms, crusts are likely to be beneath others. At the same time, they are frequently grazed by herbivores (e.g. limpets, chitons, urchins) that forage best on flat, smooth surfaces. Thus survival, for many crusts, must encompass tolerating or preventing overgrowth and avoiding or recovering from herbivory.

The ecological advantages of increased growth rates are obvious. More rapid utilization of space may influence competitive outcomes in crust-crust overgrowth interactions (e.g. Steneck et al. 1991). Lateral growth rates increased with thallus size in 3 species (Fig. 2, Table 2), most dramatically for the coralline species 
Lithothamnion phymatodeum. A possible interpretation of significant size-dependent growth is that photosynthates synthesized throughout the thallus are transported to the growing margin (discussed below). Significant size-dependent growth rates were also found for Ralfsia pacifica and Pseudolithophyllum neofarlowii (Table 2). None of the other crusts showed significant patterns. This lack of demonstrated effect could be related to small sample sizes or variable thallus 'health' under the experimental conditions (Dethier 1994), or because those species do not have the capacity to shunt photosynthates to a growing margin.

Algal crusts often dominate in heavily grazed or otherwise disturbed habitats (Steneck \& Dethier 1994) where they may have few competitors but must have mechanisms for withstanding tissue removal. All crusts, like colonial invertebrates, are hard to kill inasmuch as it is unlikely that all the tissue or modules will be removed by a grazer (especially since most crusts are broadly attached to the substratum), and remaining tissue can readily regenerate. Some crusts persist by being disturbance-resistant (i.e. hard to bite or to remove from the substratum, Steneck \& Watling 1982, Dethier 1994), whereas others simply heal wounds rapidly, resulting in no net loss under disturbed conditions. Healing rates and mechanisms varied widely, with some slow-growing species (e.g. Rhodophysema elegans) proving to be surprisingly rapid regenerators; this species must be able to regenerate meristems rapidly. In all species, shallow wounds, which can be healed by activating only vertical meristems, tended to heal much faster than deep wounds (Fig. 3A); since the latter bared the substratum, new lateral meristems were needed to fill the gap from the side. Age of the crust thallus may affect regeneration ability. Ralfsia pacifica was highly variable in its regeneration rate, probably because samples varied in age; old thalli show natural senescence (Dethier 1987, 1994) and evidently lose their ability to reform meristems. Crust species that grew rapidly in the experiments also showed the greatest ability to reform active meristems at much of the damaged perimeter; this was seen in the strong correlation between the overall rate of lateral growth and the proportion of the perimeter that regrew following transplantation.

Growth responses to artificial disturbance were also highly variable. Pseudolithophyllum whidbeyense actually grew more rapidly when wounded. Some sponges similarly show increased lateral growth rates following wounding (Ayling 1983), and Ralfsia verrucosa in South Africa shows increased photosynthetic rates following herbivory by its mutualist limpet (McQuaid \& Froneman 1993). In contrast, in Peyssonnelia pacifica and 'Petrocelis', radial growth rates of wounded crusts decreased (Fig. 5), suggesting that photosynthates may have been shunted away from growing margins to facilitate wound healing. As far as we know, these are the first examples of an injury in one area of an algal thallus causing a growth response elsewhere. There were no significant growth responses among the other 6 crusts tested (Fig. 5).

In the absence of intense disturbance, crusts in nature are easily covered by a wide range of organisms (reviewed in Dethier 1994) or debris (Steneck 1997). Some crusts seem to be able to survive being overgrown, even for years (reviewed by Miles \& Meslow 1990, Morcom et al. 1997, Airoldi 2000). In some cases, a covering of other organisms may protect the crusts from desiccation (e.g. Figueiredo et al. 2000), but generally crust growth is reduced. Two very different adaptive responses to overgrowth could include supporting the shaded region by allocating photosynthates in that direction (presumably thus reducing possible investment into lateral growth), or escaping the competitor by accelerating growth at uncovered margins. When we simulated overgrowth by experimentally shading over $75 \%$ of crust surfaces (Figs 1, $6 \& 7$ ), both types of responses were observed.

If crusts are allocating energy to support a covered portion of the thallus, the covered portion should show little change in area or growth, but the uncovered portion might show decreased growth relative to controls. All crusts tested showed a net loss in area under the disk, which reflects both survival and growth, although for some this reduction was minor. For example, Pseudolithophyllum neofarlowii had nearly zero areal change and remained pigmented in the covered portions of its thalli. This coralline and the fleshy 'Petrocelis' may have shunted photosynthates to their covered regions, as evidenced by the uncovered margins growing less than did the controls (Fig. 6A,B). Hildenbrandia occidentalis showed some paling after $1 \mathrm{yr}$, but in general was remarkably unaffected by this lengthy shading (Figs $6 \&$ 7). We have found pigmented Hildenbrandia spp. under barnacles and mussels (in Washington and Maine USA) that are several years old, and Bertness et al. (1983) found similar long persistence when overgrown. The mechanism here may be a metabolic one; the chronically slow growth of this genus (Dethier 1994) suggests that it has very low metabolic needs. Airoldi (2000) also found several crust species that could survive complete overgrowth for $>1$ yr and even remain fertile, essentially forming a permanent understory beneath dense algal turfs; overgrowth does not always lead to competitive displacement. In the overgrowth experiment, the best survivor was the coralline Lithothamnion phymatodeum; it did not suffer significant decreases in either maximum lateral growth or in thallus thickness under the disk. Thus it appears to be uniquely unaffected by shading, consistent with reports that it survives being heavily fouled by epiphytes (Steneck \& Paine 1986). 
Only Lithophyllum impressum showed the opposite response: an increase in thallus area (and to a lesser extent in marginal growth) at the uncovered region of the shaded samples. Unlike the other 3 corallines, it did not maintain its color in the shaded region; these 2 responses suggest resources being shunted away from the covered area.

All species became thinner in covered portions of their thalli, as is probably advantageous in nature under low-light conditions. Shading also usually caused new growth to be thinner than in the control crusts (Fig. 7B). In the field, thicknesses of crust thalli generally correspond with the productivity potential of their environment, such that, for any given species, crusts are thickest in the least stressful conditions (Dethier 1987, Dethier et al. 1991 for fleshy crusts, Steneck 1986 for corallines). Only a narrow band of photosynthetic tissue is illuminated at low light, so thick crusts must support much nonphotosynthetic tissue. Conversely, in high light thicker crusts are thought to be more resistant to disturbances (Steneck 1983, 1986) and competitively superior (Steneck et al. 1991, Morcom et al. 1997). In the experiments, thinning thalli in the uncovered portions of shaded crusts for Pseudolithophyllum whidbeyense and $P$. neofarlowii again suggest that these species may have been allocating resources to their covered portions.

The crusts used in the experiments came from a variety of intertidal and shallow subtidal habitats, where they are subject to very different physiological stresses (e.g. some are regularly desiccated, others are not) and herbivore regimes. In addition, they come from a variety of phylogenetic backgrounds. Thus it is not surprising to see the range of responses exhibited to common experimental conditions. One hypothesis that could explain some of the differences among species is that crusts with anatomical features such as cell-cell fusions or a large hypothallus (see Table 1) enhance intrathallus communication. While all organisms are presumably internally integrated to some degree, the extent to which parts of an individual or a clone share resources appears to vary, and in many cases the mechanisms of this integration are unknown. The encrusting algae that were able to respond to a stimulus in one part of the thallus by altering growth rate or thickness in another part may be better integrated anatomically and physiologically.

While physiological integration has not been studied in algal crusts, other algae possess anatomical features that appear to function as conduits for photosynthates (see 'Introduction'), although evidence of integration and translocation in algae is still debated (Pueshel 1990, Murray \& Dixon 1992). Potential integrating features found in crusts include cell fusions, primary and secondary pits, and a significant laterally directed hypothallus. Table 1 lists which of these potential integrating features are possessed by the different crust species studied. A number of the experimental results are consistent with the importance of these features, especially abundant cell-cell fusions, in allowing intrathallus integration. For example, Lithothamnion phymatodeum was remarkable in its ability to survive overgrowth, perhaps because its abundant cell fusions permitted photosynthates to be shunted to shaded portions. It also showed the strongest size-dependent growth. In contrast, Lithophyllum impressum (which not only lacks cell fusions but has a minimal hypothallus) performed poorly when covered. Among the noncoralline species, Ralfsia pacifica (which lacks cell fusions but has a thick hypothallus) showed sizedependent growth, although it too did very poorly when covered; it is possible that the hypothallus may transport photosynthates only outwards, towards the growing edge. The fact that some species were able to show a significant response (e.g. accelerated or decelerated growth) at a distance from a stimulus (wound or shade) strongly suggests that they have a mechanism allowing intrathallus communication. Direct physiological work testing the supposition that fusions and hypothalli act to integrate thalli would be a logical sequel to this ecological study.

Other results illustrate that mechanisms besides possible anatomical integration are important to the responses of some crusts. For example, the maximum lateral growth of Lithothamnion phymatodeum (with its abundant cell fusions) was not the fastest observed (Table 2), while Peyssonnelia pacifica (which has no perithallial fusions and only a small hypothallus) grew very rapidly. Lateral growth rates could be influenced by cell sizes or chemical defenses of crusts in ways that have no bearing on intrathallus integration. Integrating features also did not correspond perfectly to ability to survive overgrowth; Hildenbrandia occidentalis, for example, lacks any suspected integrating features and yet maintained healthy pigmentation even when covered by a disk for a year, while 'Petrocelis' possesses a number of suspected anatomical connections but did not 'maintain' covered tissue. The ecological and evolutionary milieu of each species will affect the types of responses it will show; for instance, 'Petrocelis' is often associated (Dethier 1994) with abundant herbivores in nature and thus requires rapid wound-healing reactions, but may seldom be overgrown because of the cleaning action of its grazers.

Recruitment rates of crusts were not included in this study but have been discussed elsewhere (Dethier 1994) and clearly contribute to the persistence of some of the species that otherwise might have trouble surviving competition and/or herbivory. Ralfsia pacifica and Rhodophysema elegans, for example, both recruit 
widely and frequently in the field (Dethier 1994). Airoldi (2000) similarly found that colonization is a more effective space-grabbing process than is lateral growth for some crusts, and Kaehler \& Williams (1997) note that where adult mortality is greater than lateral regrowth, persistence may depend entirely on recruitment.

Some of the patterns in the results may occur because phylogenetically related species respond in similar ways (Harvey \& Pagel 1991) rather than because of cross-taxa features such as cell fusions. Although there were no response patterns consistently relating to algal division, in general the corallines (all in one order) responded more similarly to the manipulations than did the non-coralline red crusts. Among the corallines, the 2 Pseudolithophyllum species responded more similarly to each other than to the other species.

Variation among crusts in anatomical features that may relate to intrathallus integration could contribute to the observed ecological latitude within this growth form (Dethier 1994). However, crusts use a variety of strategies such as rapid vertical regrowth, opportunistic life histories, and perhaps reduced metabolic rate to survive in environments where they are among the lowest and slowest of benthic marine organisms.

Acknowledgements. Assistance in many aspects of this project was provided by Cathy Pfister and David Duggins. Ann Haskins lovingly wounded and tended the crusts, took the photographs, and kept track of everything. Dianna Padilla, Aaren Freeman and others provided energetic constructive criticism of previous drafts. A.O.D. Willows and staff provided facilities and support at the Friday Harbor Labs. The research was supported by NSF grants OCE 8315136 and OCE 8600262 .

\section{LITERATURE CITED}

Adey WH, Sperapani CP (1971) The biology of Kvaleya epilaeve, a new parasitic genus and species of Corallinaceae. Phycologia 10:29-42

Adey WH, Masaki T, Akioka H (1974) Ezo epiyessoense, a new parasitic genus and species of Corallinaceae (Rhodophyta, Cryptonemiales). Phycologia 13:329-344

Airoldi L (2000) Effects of disturbance, life histories, and overgrowth on coexistence of algal crusts and turfs. Ecology 81:798-814

Ayling AL (1983) Growth and regeneration rates in thinly encrusting Demospongiae from temperate waters. Biol Bull 165:343-352

Bertness MD, Yund PO, Brown AF (1983) Snail grazing and the abundance of algal crusts on a sheltered New England rocky beach. J Exp Mar Biol Ecol 71:147-164

Bosence DWJ (1983) Coralline algal reef frameworks. J Geol Soc Lond 140:365-376

Cabioch J, Giraud G (1982) La structure hildenbrandioide, strategie adaptative chez les Floridées. Phycologia 21: 307-315

Denizot M (1968) Les algues Floridées encroutantes (à l'ex- clusion des Corallinacées). Muséum national d'Histoire naturelle, Paris

Dethier MN (1987) The distribution and reproductive phenology of intertidal fleshy crustose algae in Washington. Can $\mathrm{J}$ Bot 65:1838-1850

Dethier MN (1994) The ecology of intertidal crusts: variation within a functional group. J Exp Mar Biol Ecol 177:37-71

Dethier MN, Paull KM, Woodbury MM (1991) Distribution and thickness patterns in subtidal encrusting algae from Washington. Bot Mar 34:201-210

Dixon PS, Irvine LM (1977) Miscellaneous notes on algal taxonomy and nomenclature. IV. Bot Not 130:137-142

Figueiredo MA de O, Kain (Jones) JM, Norton TA (2000) Responses of crustose corallines to epiphyte and canopy cover. J Phycol 36:17-24

Fletcher RL (1977) The life-history of Rhodophysema elegans in laboratory culture. Mar Biol 40:291-298

Goff LJ, Cole K (1973) The biology of Harveyella mirabilis (Cryptonemiales, Rhodophyceae). II. Carposporophyte development as related to the taxonomic affiliation of the parasitic alga, Harveyella mirabilis. Phycologia 14: $227-238$

Grant SWF, Knoll AH, Germs GJB (1991) Probable calcified metaphytes in the latest proterozoic Nama group, Namibia: origin, diagensis and implications. J Paleont 65:1-18

Harvey PH, Pagel MD (1991) The comparative method in evolutionary biology. Oxford University Press, Oxford

Hollenberg GJ (1969) An account of the Ralfsiaceae (Phaeophyta) of California. J Phycol 5:290-301

Hughes TP (1984) Population dynamics based on individual size rather than age: a general model with a reef coral example. Am Nat 123:778-795

Irvine LM (1977) Seaweeds of the British Isles. Vol 1 Rhodophyta. Part 2A. Cryptonemiales (sensu stricto), Palmariales, Rhodymeniales. British Museum (Natural History), London

Jackson JBC, McKinney FK (1990) Ecological processes and progressive macroevolution of marine colonal benthos. In: Ross RM, Allmon WD (eds) Causes of evolution. A paleontological perspective. University of Chicago Press, Chicago, p 173-209

Jackson JBC, Buss LW, Cook RE (1985) Population biology and evolution of clonal organisms. Yale University Press, New Haven

Jahns HM (1973) Anatomy, morphology, and development. In: Ahmadjian V, Hale ME (eds) The lichens. Academic Press, New York, p 3-58

Kaehler S, Williams GA (1997) Do factors influencing recruitment ultimately determine the distribution and abundance of encrusting algae on seasonal tropical shores? Mar Ecol Prog Ser 156:87-96

Kaehler S, Williams GA (1998) Early development of algal assemblages under different regimes of physical and biotic factors on a seasonal tropical rocky shore. Mar Ecol Prog Ser 172:61-71

Kremer BP (1983) Carbon economy and nutrition of the alloparasitic red alga Harveyella mirabilis. Mar Biol 76:231-239

Lidgard S, Jackson JBC (1989) Growth in encrusting cheilostome bryozoans. I. Evolutionary trends. Paleobiology 15: 255-282

Masuda M, Ohta M (1981) A taxonomic study of Rhodophysema elegans (Rhodophyta) from Japan. Acta Phytotax Geobot 32:75-89

McQuaid CD, Froneman PW (1993) Mutualism between the territorial intertidal limpet Patella longicosta and the crustose alga Ralfsia verrucosa. Oecologia 96:128-133 
Miles AK, Meslow EC (1990) Effects of experimental overgrowth on survival and change in the turf assemblage of a giant kelp forest. J Exp Mar Biol Ecol 135:229-242

Miles JS, Harvell CD, Griggs CM, Eisner S (1995). Resource translocation in a marine bryozoan: quantification and visualization of ${ }^{14} \mathrm{C}$ and ${ }^{35} \mathrm{~S}$. Mar Biol 122:439-445

Morcom NF, Ward SA, Woelkerling WJ (1997) Competition of epiphytic nongeniculate corallines (Corallinales, Rhodophyta): overgrowth is not victory. Phycologia 36:468-471

Murray SN, Dixon PS (1992) The Rhodophyta: some aspects of their biology. III. Oceanogr Mar Biol Annu Rev 30:1-148

Nicholson NL, Briggs WR (1972) Translocation of photosynthate in the brown alga Nereocystis. Am J Bot 59:97-106

Pueschel CM (1990) Cell structure. In: Cole KM, Sheath RG (eds) Biology of the red algae. Cambridge University Press, Cambridge, p 7-41

Sammarco PW, Coll JC (1990) Lack of predictability in terpenoid function. Multiple roles and integration with related adaptations in soft corals. J Chem Ecol 10:273-289

South GR, Whittick A (1987) Introduction to phycology. Blackwell Scientific Publication, Oxford

Steneck RS (1983) Escalating herbivory and resulting adaptive trends in calcareous algal crusts. Paleobiology 9:44-61

Steneck RS (1986) The ecology of coralline algal crusts: convergent patterns and adaptive strategies. Annu Rev Ecol Syst 7:273-303

Editorial responsibility: Otto Kinne (Editor),

Oldendorf/Luhe, Germany
Steneck RS (1997) Crustose corallines, other algal functional groups, herbivores and sediments: complex interactions among reef productivity gradients. Proc 8th Int Coral Reef Symp 1:695-700

Steneck RS, Dethier MN (1994) A functional group approach to the structure of algal-dominated communities. Oikos 69:476-498

Steneck RS, Paine RT (1986) Ecological and taxonomic studies of shallow-water encrusting Corallinaceae (Rhodophyta) of the boreal northeastern Pacific. Phycologia 25: 221-240

Steneck RS, Watling L (1982) Feeding capabilities and limitation of herbivorous molluscs: a functional group approach. Mar Biol 68:299-319

Steneck RS, Hacker SD, Dethier MN (1991) Mechanisms of competitive dominance between crustose coralline algae: an herbivore-mediated competitive reversal. Ecology 72 : 938-950

Swinscow TDV (1968) Pyrenocarpous lichens: 13. Freshwater species of Verrucaria in the British Isles. Lichenologist 4: $34-54$

Vadas RL, Steneck RS (1988) Zonation of deep water benthic algae in the Gulf of Maine. J Phycol 24:338-346

Williams SL (1984) Uptake of sediment ammonium and translocation in a marine macroalga Caulerpa cupressoides. Limnol Oceanogr 29:374-379

Submitted: December 13, 2000; Accepted: April 20, 2001

Proofs received from author(s): November 2, 2001 